\title{
Effect of social anxiety on self-esteem of special need university students in the war-affected region
}

\author{
S. Mudasser Shah ${ }^{1,2,{ }^{*}}$, Nadia Hameed ${ }^{2}$, Fatima Afsar ${ }^{3}$, Summiya Ahmad ${ }^{2}$, Tauseef Ahmad ${ }^{4, *}$
}

${ }^{1}$ Psychiatry and Psychosomatic Department, Southeast University, Nanjing (210009), China

${ }^{2}$ Department of Psychology, University of Peshawar, Khyber Pakhtunkhwa, Islamic Republic of Pakistan

${ }^{3}$ Psychology Department, Quaid-e-Azam University, Islamabad, Islamic Republic of Pakistan

${ }^{4}$ Department of Epidemiology and Health Statistics, School of Public Health, Southeast University, Nanjing (210009), China

\section{Correspondence}

S. Mudasser Shah, Psychiatry and Psychosomatic Department, Southeast University, Nanjing (210009), China Email: mudasser.shah35@gmail.com

Correspondence

Tauseef Ahmad, Department of Epidemiology and Health Statistics, School of Public Health, Southeast University, Nanjing (210009), China

Email: tahmad@seu.edu.cn

History

- Received: 2019-12-31

- Accepted: 2020-02-09

- Published: 2020-03-02

DOI : 10.15419/ajhs.v6i1.462

\section{Check for updates}

Copyright

(c) Biomedpress. This is an openaccess article distributed under the terms of the Creative Commons Attribution 4.0 International license.

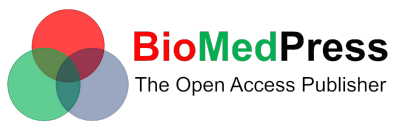

ABSTRACT

This study aimed to investigate the correlation between social anxiety and self-esteem among the special need university students from Peshawar city, Khyber Pakhtunkhwa, Pakistan. The sample size was comprised of 100 disable university students aged 18-30 years, out of which 50 were male and 50 were female. A correlational study was designed. The social anxiety levels of the recruited subjects were determined through Liebowitz Social Anxiety Scale. The level of self-esteem was determined through the standard self-report mechanism by applying the Rosenberg Self-esteem Scale. The data collected were tabulated, analyzed and interpreted through SPSS software, Version 23, for windows, by using means, percentages, Pearson's product-moment correlation coefficient $(r)$ and Independent sample t-test. On average, the students with high social anxiety and low levels of self-esteem were found ( $r=-620)$, social anxiety of female students was high $(M=78.14, S D=14.67)$ as compared to male students $(M=59.34, S D=14.41)$. However, the self-esteem of female students $(M=16.08, S D=1.77)$ was the same as compared with male students $(M=16.38, S D=1.86)$. There was a significant negative relationship found between social anxiety and self-esteem. The social anxiety of female disable university students was high, however, the male and female disable university students have the same self-esteem. Further studies are recommended on a large scale to explore certain other issues that are related to the given variables.

Key words: Social anxiety, Self-esteem, University students

\section{INTRODUCTION}

Social anxiety is characterized by a fear that what other will think about them particularly the fear of rejection, criticism and humiliation. Due to this feeling, an individual feels insecure in a group, and that feeling automatically leads to his/her rejection by the group to which he/she belongs ${ }^{1}$. Every individual need to be liked approved and valued in social set up to extend helpful peer relationships. Evolutionary Psychologists consider the social anxiety as a competitive anxiety, which arises in social situations and the individual would defend or like his/her social standing in front of others ${ }^{2}$.

Low social anxious individuals are less defensive than high anxious individuals. The involuntary thoughts were experienced more in Individuals with high social anxiety. Previous studies reported that these thoughts are negative and troubling and interfere with their attention $^{3}$. Individual with high social anxiety were involve in defensive processing and negatively affect their confidence and $\operatorname{mood}^{4}$.

Self-esteem is the individual overall subjective emotional assessment of his or her own worth. Average self-esteem pays important role in happiness, academic achievement, relationships and satisfaction in marriage ${ }^{5}$.

Education is necessary for social survival of human. According to Pakistan education policy, "Education for all" which provide equal opportunity of education to both able and disable individuals. Special schools have been established for disable individuals but still most of them are getting education in main stream. The literature is insufficient on the problems for disable individuals getting educated. Therefore, the study aimed to highlights the correlation between social anxiety and self-esteem among the special need university students.

\section{MATERIALS AND METHODS}

\section{Study design}

A correlational study was designed.

\section{Sampling method}

A convenient sampling method was used.

\section{Study population}

The total sample was comprised of $100(n=100)$ disabled university students. The sample were categorized into two groups, male disabled students 
$(n=50)$, and female disabled students $(n=50)$. The students were recruited from Peshawar University, Islamia College University, Agriculture University, Khyber Medical College, University of Engineering and Technology, Sarhad University of Information Technology, Pristion University, Gandahara University, Abasin University, Iqra University, City University, Qurtaba University, CESOS University and Peshawar Medical College. The included students aged between 18-30 years, and were student of BS, Master, MS, MPhil, and PhD degree program. The information was collected using a pre-tested self-designed questionnaire. The obtained information includes socio-demographic factors, and substance use factors.

\section{Social anxiety assessment}

In order to assess social anxiety disorder Liebowitz Social Anxiety Scale (LSAS-SR) was used ${ }^{6}$. The scale comprised of 24 items, and two subscales in which 13 questions related to performance anxiety and 11 questions are concerned with social situations. The score of LSAS-SR is compared with total fear, fear of performance, fear of social interaction, avoidance of social interaction, total avoidance and avoidance of performance they are highly correlations of 0.94 and 0.92 respectively. The internal consistency of LSAS-SR is $\mathrm{a}=0.92$.

\section{Self-esteem assessment}

Rosenberg Self-esteem Scale (RSES) was used for assessing self-esteem ${ }^{7}$. The scale comprised of 10 items and start from strongly agree to strongly disagree; having four options strongly agree mark as 3, agree 2 , disagree 1 and strongly disagree 0 . Individual has high score on scale have high self-esteem. The internal consistency of RSES is 0.77 and an alpha coefficient is 0.72 to 0.87 . The test retest reliability of RSES for two weeks is 0.85 and for seven months is 0.63 . The total score is 30 and individual with score from 15 to 25 is average while below from 15 individual have low self-esteem. Scores for items 1,2,4,6 and 7 are strongly agree $=3$, agree $=2$, disagree $=1$ and for strongly disagree $=0$ while scores for items $3,4,8,9$, and 10 are strongly agree $=0$, agree $=1$, disagree $=2$ and strongly disagree $=3$, the high score indicates higher self-esteem.

\section{Data analysis}

Data were analyzed through Statistical Package for Social Sciences (SPSS, v. 23) by using means, percentages, Pearson's product moment correlation coefficient ( $r$ ) and Independent sample t-test. The association evaluated by adjusted odds ratio (CI: 95\%), and p-values less than 0.05 were considered statistically significant.

\section{Ethical approval}

This study was approved by the ethical research committee of Department of Psychology, University of Peshawar. The head of each department was being informed for permission of collecting data and the students were briefed before filling the questionnaire. An informed consent was signed from each participant. The students were informed about the significance of this study and importance of reliable responses. Furthermore, their responses were kept confidential and were used purely for only academic and research purposes.

\section{RESULTS}

Of the total included study participants 82 (82\%) were by birth disabled and 18 (18\%) were accidental disabled. Out of the participants 52 (52\%) were science students and 48 (48\%) were arts students, 48 (48\%) were from government education background, $57(57 \%)$ student's grades were between 60-70, 22 (22\%) were from lower socioeconomic status, and 47 (47\%) were coming from the rural residence as shown in Table 1. The LSAS mean score was 68.78 (SD = 17.28) minimum score was 30 , maximum score was 110 , and Cronbach alpha reliability was 0.89 . The RSES mean score was $16.23(\mathrm{SD}=1.81)$, minimum score was 12 , maximum score was 20 , and Cronbach alpha reliability was 0.76 (Table 2 ). The LSAS were significantly negatively associated with RSES, $r=-620$, $\mathrm{p}<0.01$ (Table 3 ). When the level of social anxiety increases, then the level of self-esteem decreases. An independent sample t-test value shows that male score $(\mathrm{M}=59.34, \mathrm{SD}=14.41)$ on LSAS was significantly lower than female $(M=78.14, S D=14.67), t$ (98) $-6.462, p<0.01$. While the difference on RSES between male $(\mathrm{M}=16.38, \mathrm{SD}=1.86)$ and female $(\mathrm{M}=$ $16.08, \mathrm{SD}=1.77), \mathrm{t}(98) 0.826, \mathrm{p}>0.05$, was not statistically significant (Table 4$)$.

\section{DISCUSSION}

According to estimates of World Health Organization (WHO), about $15 \%$ of the world's population lives with some form of disability. Of which $2-4 \%$ individuals experience significant difficulties in their life. At some point in life almost everyone human will be temporarily or permanently impaired. However, the individuals who survive to old age will experience the 


\begin{tabular}{|c|c|c|c|}
\hline Variable & Categories & Frequency & Percentage \\
\hline \multirow[t]{2}{*}{ Gender } & Male & 50 & 50 \\
\hline & Female & 50 & 50 \\
\hline \multirow[t]{2}{*}{ Disability } & By birth & 82 & 82 \\
\hline & Accidental & 18 & 18 \\
\hline \multirow[t]{2}{*}{ Area of study } & Science & 52 & 52 \\
\hline & Arts & 48 & 48 \\
\hline \multirow[t]{2}{*}{ Education background } & Private & 52 & 52 \\
\hline & Government & 48 & 48 \\
\hline \multirow[t]{3}{*}{ Socioeconomic Status } & Lower & 22 & 22 \\
\hline & Middle & 45 & 45 \\
\hline & High & 33 & 33 \\
\hline \multirow[t]{4}{*}{ Grades } & $50-60$ & 6 & 6 \\
\hline & $60-70$ & 57 & 57 \\
\hline & $70-80$ & 35 & 35 \\
\hline & $80+$ & 2 & 2 \\
\hline \multirow[t]{2}{*}{ Living Area } & Urban & 53 & 53 \\
\hline & Rural & 47 & 47 \\
\hline
\end{tabular}

Table 2: Psychometric properties of the major study variables

\begin{tabular}{|c|c|c|c|c|c|c|c|c|}
\hline Scales & & M & SD & $\alpha$ & Minimum & Maximum & Range & Skew \\
\hline $\begin{array}{l}\text { Leibowitz Social } \\
\text { Anxiety Scale }\end{array}$ & 100 & 68.78 & 17.28 & .89 & 30 & 110 & 80 & .051 \\
\hline $\begin{array}{l}\text { Rosenberg Self- } \\
\text { esteem Scale }\end{array}$ & 100 & 16.23 & 1.81 & .76 & 12 & 20 & 8 & .092 \\
\hline
\end{tabular}

Note: $\mathrm{M}=$ Mean; $\mathrm{SD}=$ Standard Deviation

$\begin{aligned} & \text { Table 3: Correlations between social anxiety and } \\
& \text { self-esteem }\end{aligned}$
\begin{tabular}{llllll} 
& & & & \\
Variables & $\mathrm{S}$ & $\mathrm{SD}$ & 1 & 2 \\
1. Social Anxiety & 64.95 & 11.20 & 1 & \\
2. Self-esteem & 8.84 & 8.23 & $-620^{* *}$ & 1 \\
\hline Note: $\left(^{* *}\right)=\mathrm{p}<0.01$ & & & &
\end{tabular}




\begin{tabular}{|c|c|c|c|c|c|c|c|c|}
\hline \multirow[t]{2}{*}{ Variables } & \multicolumn{2}{|c|}{ Male } & \multicolumn{2}{|c|}{ Female } & \multirow[t]{2}{*}{$t$} & \multirow[t]{2}{*}{$p$} & \multirow{2}{*}{$\begin{array}{c}\text { LL, UL } \\
(95 \% \mathrm{CI})\end{array}$} & \multirow[t]{2}{*}{ Cohen's d } \\
\hline & M & $\mathrm{SD}$ & M & $\mathrm{SD}$ & & & & \\
\hline $\begin{array}{l}\text { Social } \\
\text { Anxiety }\end{array}$ & 59.34 & 14.41 & 78.14 & 14.67 & -6.462 & 0.000 & $\begin{array}{c}{[-24.57} \\
-13.2]\end{array}$ & 1.292 \\
\hline $\begin{array}{l}\text { Self- } \\
\text { esteem }\end{array}$ & 16.38 & 1.86 & 16.08 & 1.77 & 0.826 & 0.411 & $\begin{array}{c}{[-0.42} \\
1.02]\end{array}$ & 0.165 \\
\hline
\end{tabular}

Note: $\mathrm{M}=$ Mean; $\mathrm{SD}=$ Standard Deviation; $\mathrm{CI}=$ Confidence interval; $\mathrm{LL}=$ Lower limit, $\mathrm{UL}=$ Upper limit.

increasing consequences and difficulties in functioning $^{8}$. Disability of an individual caused directly by disease, injury or other health conditions and requires medical care and treatment ${ }^{9}$. This study aimed to highlights the social anxiety and self-esteem among the disable university students.

Our result shows negative correlation between social anxiety and self-esteem. The finding of our study is in line with other published studies ${ }^{10,11}$. Another study by $\mathrm{Xu}$ et al. ${ }^{12}$ recorded that the lifetime prevalence of social anxiety disorder was high in women $(5.67 \%)$ as compared to men $(4.20 \%)$. In our study, social anxiety among female disable university students was high as compared to male students. However, the male and female disable university students have same selfesteem level. A study conducted by Fatima et al. ${ }^{13}$ reported high level of self-esteem and social connectedness in women while the social anxiety was to be high in man.

The psychological factors such as social anxiety and self-esteem have a remarkable influence over the academic, personal, vocational and social life of an individual. It has been proved that an optimum level of social anxiety has significant contributions in improving academic grades of students. The present study will be helpful for the students and researchers to advance their knowledge. Furthermore, it will be supportive for the university teachers in adopting proper strategies to optimize the social anxiety towards their improved academics. In addition, this study may be useful for the university students to know the causes of their severe social anxiety (if any), and to overcome on it and how to improve their self-esteem towards improvement of their academics.

\section{CONCLUSIONS}

There was a significant negative relationship found between social anxiety and self-esteem. Social anxiety of female disable university students were high, however, the male and female disable university students have same self-esteem.

\section{AUTHORS' CONTRIBUTIONS}

Conceptualization and methodology: SMS, NH and SA; Data curation, SMS and FA; Writing-original draft preparation, SMA and TA; Review and editing, TA; supervision, NH and SA. All authors have read and agreed to the published version of the manuscript.

\section{FUNDING}

This research received no external funding.

\section{ACKNOWLEDGMENTS}

We acknowledge all the study participants and their respective universities.

\section{CONFLICTS OF INTEREST}

The authors declare no conflicts of interest.

\section{REFERENCES}

1. Garcia-Lopez LJ. Tratando... trastorno de ansiedad social (Treating...social anxiety disorder). Madrid: Piramide; 2013.

2. Beidel DC, Turner SM. American Psychological Association. Shy children, phobic adults: Nature and treatment of social anxiety disorder. Washington (DC): American Psychological Association; 2007.

3. Vassilopoulos SP. Anticipatory processing in social anxiety. Behav Cogn Psychother. 2004;32(3):303-11. Available from: 10.1017/S1352465804001377.

4. Hinrichsen $\mathrm{H}$, Clark DM. Anticipatory processing in social anxiety: two pilot studies. J Behav Ther Exp Psychiatry. 2003;34(34):205-18. PMID: 14972668. Available from: 10.1016/S00057916(03)00050-8.

5. Orth U, Robins RW. The development of self-esteem. Curr Dir Psychol Sci. 2014;23(5):381-7. PMID: 25485608. Available from: 10.1177/0963721414547414.

6. Liebowitz MR. Social phobia. Mod Probl Pharmacopsychiatry. 1987;22:141-73. PMID: 2885745. Available from: 10.1159/ 000414022 .

7. Rosenberg M. Society and the adolescent self-image. Princeton (NJ): Princeton University Press; 1965. Available from: $10.1515 / 9781400876136$.

8. World Health Organization. World report on disability. World Health Organization 2011. Available online from https://www .who.int/disabilities/world_report/2011/report/en/ [accessed on December 29, 2019]. 
9. Mitra S. The capability approach and disability. J Disabil Policy Stud. 2006;16(4):236-47. Available from: 10.1177/ 10442073060160040501.

10. Ahmad ZR, Bano N, Ahmad R, Khanam SJ. Social anxiety in adolescents: does self-esteem matter. Asian Journal of Social Sciences and Humanities. 2013;2(2):91-8.

11. Liaqat $S, A k r a m$ M. Relationship between Self-Esteem and Social Anxiety among Physically Handicapped People. International Journal of Innovation and Scientific Research.
2014:9(2):307-16.

12. Xu Y, Schneier F, Heimberg RG, Princisvalle $K$, Liebowitz MR, Wang $S$. Gender differences in social anxiety disorder: results from the national epidemiologic sample on alcohol and related conditions. J Anxiety Disord. 2012;26(1):12-9. PMID: 21903358. Available from: 10.1016/j.janxdis.2011.08.006.

13. Fatima M, Niazi S, Ghayas S. Relationship between Self-Esteem and Social Anxiety: Role of Social Connectedness as a Mediator. Pak J Soc Clin Psychol. 2017;15(2):12-7. 